\title{
METHYL RED DYE REMOVAL USING NEW BIO-SORBENTS DERIVED FROM HYACINTH AND TINOSPORA CORDIFOLIA PLANTS FROM WASTE WATERS
}

\author{
K. Venkata Ramana ${ }^{1,3}$, K. Swarna Latha ${ }^{3}$, K. Ravindranath ${ }^{1,2}$ \\ and B. Hari Babu ${ }^{3 *}$ \\ ${ }^{1}$ Department of Chemistry, Bapatla Engineering College, Bapatla-522101, Guntur Dist., AP \\ ${ }^{2}$ Departmrnt of Chemistry, KL University, Vaddeswaram, Guntur Dist., AP. \\ ${ }^{3}$ Department of Chemistry, Acharya Nagarjuna University, Guntur Dist, AP \\ *E-mail: dr.b.haribabu@gmail.com
}

\begin{abstract}
The use of eco-friendly, highly efficient, locally available, and low-cost adsorbents have been investigated for removing dyes from waste water and regarded as an ideal alternative to the current expensive methods. Adsorption of methyl red from aqueous solution using dried Hyacinth and Tinospora Cordifolia is the objective of this study. It was focusing on the effect of decolourisation due to dosage of adsorbent, initial concentration of solution, $\mathrm{pH}$, contact time and the equilibrium of adsorption was modelled by different parameters. Prime $\mathrm{pH}$ value for dye adsorption was found to be 4.In the removal of the dye than raw bio-materials, ashes of the bio-materials are more effective. Percentage of extraction is effected in presence fivefold excess of anions. Trivalent anion, divalent, monovalent is the order of the interference. Co-cations have showed less interference. The developed methodologies are enact to industrial samples.

Keywords: Methyl Red (MR), pollution control, Bio-adsorbents, adsorption isotherm, Kinetics, equilibrium models.

(C) RASĀYAN. All rights reserved
\end{abstract}

\section{INTRODUCTION}

Azo, vat, nitro, indigo etc., are some of the types of synthetic dyes which are popularly used for different purposes in printing, paper, textile industry and pulp manufacturing. ${ }^{1-3}$ Effluent discharged from the textile industries has variable characteristics in terms of organic and inorganic chemical contents, dissolved oxygen, $\mathrm{pH}$, etc. Due to durability of the dyes in wastewater, dye effluent pollution is caused. ${ }^{4}$ Coagulation followed by biological treatment, $\mathrm{pH}$ neutralization are utilized by existing effluent treatment procedures. Instead from effluents they are unable to remove recalcitrant dyes completely. This is because of the resistance of dyes to degradation, stability and colour fastness. ${ }^{5}$

A considerable amount of waste water is generated having strong colour, heavy metals, a large amount of suspended solids, sulphides, a highly fluctuating $\mathrm{pH}$ salts, chlorine, temperature and COD concentration. ${ }^{6}$ Untreated textile wastewater disposal pretends to be a high threat to the environment. It captures a share of $15-20 \%$ of total wastewater in the country. ${ }^{7}$ As the synthetic dyes are not biodegradable, conventional methods based on biodegradation is not effective in the controlling of the dye pollution. ${ }^{89}$ The popular techniques such as ion-exchange, Electro-kinetic coagulation, electrochemical oxidation, membrane filtration, and photo-catalytic degradation process ${ }^{10-16}$ are expensive and are not applicable for large scale treatments. We noticed affinity of some dyes towards Hyacinth (HY) and Tinospora Cordifolia (TC) plants, while probing the biomaterials of different plants for their ability to control dye pollution. The physical methods transfer the pollutants from one medium to another are merely non-destructive thus giving secondary treatment. ${ }^{17}$ Due to high dosage and production of a large quantity of sludge chemical methods are not economically viable. ${ }^{18-20}$ Thepresent paper reports the findings of degradation of Methyl Red using the HY and TC plants. 
By varying $\mathrm{pH}$, initial concentration of the Methyl red dye contact time, co-ions, temperature and adsorbent dose, the optimization of extraction conditions such as sorption nature of the active biosorbents towards Methyl red dye has been studied for the effective removal of Methyl Red from polluted waters. A comparative study has been made in the adsorption processes with Freundlich, Langmuir, Temkin and Dubinin-Radushkevich (D-R) isotherms and dynamics of adsorption have been studied using Weber and Morris intra particle diffusion, pseudo first-order, pseudo second-order, Bangham's pore diffusion and Elovich equations. The methodologies developed using biomaterials derived from the leaves and barks of HY and TC have been applied to the removal of MR from polluted waste waters.

\section{Chemicals}

\section{EXPERIMENTAL}

Analytical grade chemicals were used.

\section{Stock solution of Methyl Red}

By dissolving a requisite amount of A.R. grade Methyl Red dye in double distilled water, 100 ppm of Methyl Red solution was prepared. The solution was suitably diluted based on the requirement.

\section{Preparation of Adsorbents}

During the study of plant materials for their sorption abilities apropos the Methyl Red, it was perceived that the adsorbents derived from leaves and stems of HY and TC have shown kinship towards the Methyl red.

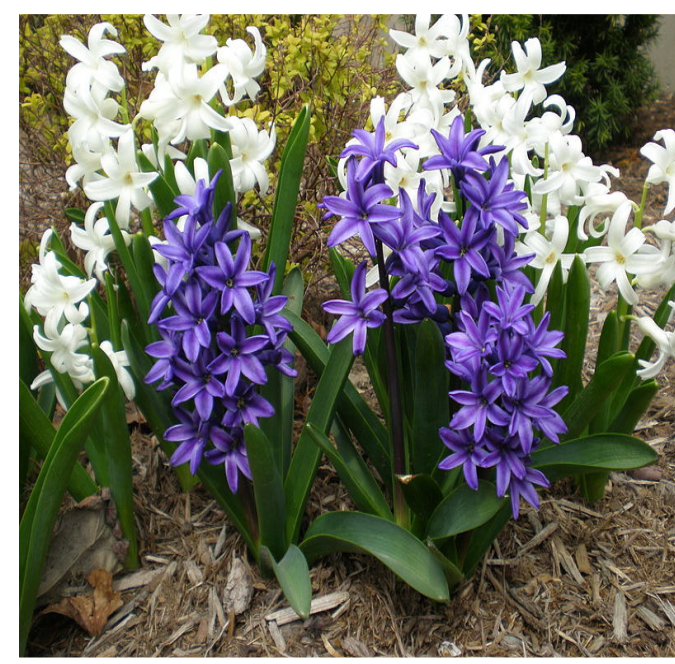

Hyacinth

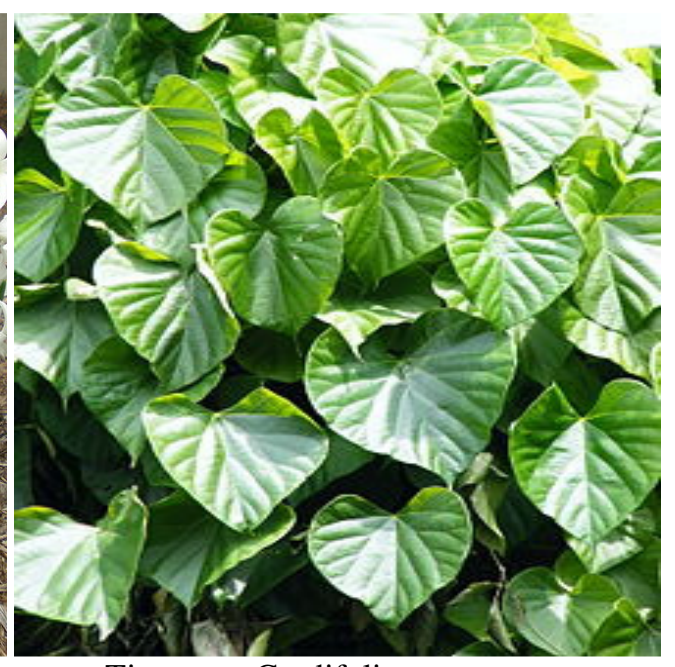

Tinospora Cordifolia

\section{Adsorption Experiment}

Fig.-1: Flora Plants showing affinity towards Methyl Red

The extraction procedure of Batch system was adopted. ${ }^{21-23}$ Circumspect weighted quantities of permeable were taken into formerly washed 1 lit/500 mL stopper bottles containing $500 \mathrm{~mL} / 250 \mathrm{~mL}$ of Methyl red dye solution of foreordained concentrations. The various primary $\mathrm{pH}$ values of the moratorium were adjusted with dil. $\mathrm{HCl}$ or dil. $\mathrm{NaOH}$ solution using $\mathrm{pH}$ meter. The samples were joggled vigorously in mechanical shakers and were allowed to be in equipoise for the desired time. After the equipoise period, an aliquot of the sample was taken for the determination of Methyl Red dye using Spectrophotometric method. The dye has $\lambda_{\max }$ at $464.9 \mathrm{~nm}$ and obeys Beers-Lambert's law at low concentrations. The Optical Density (O.D) computations were made using UV-Visible Spectrophotometer (Systronics make) at the said $\lambda_{\max }$. The retrieved O.D value for strange solution was referred to standard graphs (drawn between O.D and concentration) prepared with familiar concentrations of Methyl Red dye by incorporating Least Squares method. 
The sorption features of the permeable were studied with respect to various physicochemical attributes. At a fixed sorbent permeable, with respect to time of equilibration at various $\mathrm{pH}$ values the percentage removal of Methyl Red dye from simulated water samples was studied. Graphs A: 1-8 and B: 1-2 shows the results obtained.

For a particular sorbent at prime $\mathrm{pH}$ and equilibration times, the minimum dosage needed for the maximum removal of the Methyl Red Dye, extraction investigations were made by investigating the percentage of extraction with respect to the sorbent dosage. Graphs C: 1-4, shows the results obtained.

\section{Methyl Red dye analysis}

The percentage removal of Methyl red and amount adsorbed (in $\mathrm{mg} / \mathrm{g}$ ) were calculated using the following equations:

$$
\begin{aligned}
& \% \text { of Removal }(\% \mathrm{R})=\frac{\mathrm{Ci}-\mathrm{Ce}}{\mathrm{Ci}} \times 100 \\
& \text { Amount adsorbed }(\mathrm{qe})=\frac{\mathrm{Ci}-\mathrm{Ce}}{\mathrm{m}} \times \mathrm{V}
\end{aligned}
$$

Where, $\mathrm{Ci}=$ Initial concentration of the Methyl Red (MR) solution $\mathrm{g} / \mathrm{L}$

$\mathrm{Ce}=$ Equilibrium concentration of the Methyl Red (MR) solution in $\mathrm{mg} / \mathrm{L}$

$\mathrm{m}=$ mass of the adsorbent in grams;

$\mathrm{V}=$ Volume of Methyl Red (MR) test solution in liters

For different physical and chemical characteristics such as agitation time, adsorbent dosage, $\mathrm{pH}$ of the Methyl Red solution, particle size, initial concentration of Methyl Red solution, temperature and in presence of ions, the same procedure has been employed.

\section{Effect of other Co-Ions (Interfering Ions)}

For the study of the common ions present in natural waters, the following interfering ions are selected viz. Chloride, Carbonate, Sulphate, Nitrate, Phosphate, Calcium (II), Zinc (II),Copper (II), Magnesium (II) and Iron (II). Methyl Red dye and the co-ions synthetic mixtures are so prepared that the concentration of the foreign ion was maintained at fivefold excess than the dye concentrations. In stopper bottles $500 \mathrm{~mL}$ of these solutions are taken and then promising adsorbents (as decided by the Graphs A and B) in correctly weighted prime quantities are added. With dil. $\mathrm{HCl}$ or dil. $\mathrm{NaOH}$, prime $\mathrm{pH}$ was adjusted using $\mathrm{pH}$ meter. The samples are joggled in shaking machines for required prime periods and then few portions of the samples are taken out, filtered and analyzed for Methyl Red dye. From the data obtained, percentage of extraction was calculated.

\section{RESULTS AND DISCUSSION}

With respect to various physicochemical parameters the sorption characteristics of the bio-adsorbents were studied. The results are presented in the Graphs. A: 1-8, B: 1-2, C: 1-4; Isotherm curves 1(a)-1(h), 2(a)-2(h), 3(a)-3(h), 4(a)-4(h); kinetic parameters graphs 5(a)-5(h), 6(a)-6 (h), 7(a)-7(h), 8(a)-8(h), 9(a)-9 (h), adsorption temperature graphs 10(a)-10(h).

\section{Time of equilibration}

For a fixed adsorbent at a fixed $\mathrm{pH}$ and after certain duration the following observations are significant, percentage of extractability increases with time, the extractability remains static, i.e. an equilibrium state has been reached (Graphs: A: 1-8). During the steady state, rate of adsorption and the rate of desorption are equal. For plant materials of HY percentage of extraction of Methyl Red dye at $\mathrm{pH}: 4$ has been found to be $19.0 \%$ at $15 \mathrm{~min}, 27.0 \%$ at $30 \mathrm{~min}, 31.0 \%$ at $45 \mathrm{~min}, 40.0 \%$ at $60 \mathrm{~min}, 47.0 \%$ at $75 \mathrm{~min}$, $60.0 \%$ at $90 \mathrm{~min}, 68.0 \%$ at $105 \mathrm{~min}$ or above for leaves powders (Graphs. A: 1 ); $20.0 \%$ at $15 \mathrm{~min}, 25.0 \%$ at $30 \mathrm{~min}, 30.0 \%$ at $45 \mathrm{~min} 41.0 \%$ at $60 \mathrm{~min}, 58.0 \%$ at $75 \mathrm{~min}, 74.0 \%$ at $90 \mathrm{~min}$ and above for leaves ashes (Graphs. A: 2);19.0\% at $15 \mathrm{~min}, 28.0 \%$ at $30 \mathrm{~min}, 39.0 \%$ at $45 \mathrm{~min}, 47.0 \%$ at $60 \mathrm{~min}, 53.0 \%$ at $75 \mathrm{~min}, 64.0 \%$ at $90 \mathrm{~min}, 70.0 \%$ at $105 \mathrm{~min}, 75.0 \%$ at $125 \mathrm{~min}$ and above for stem powder (Graphs. A: 3); and 20.0\% at 15 $\min , 30.0 \%$ at $30 \mathrm{~min} 42.0 \%$ at $45 \mathrm{~min}, 54.0 \%$ at $60 \mathrm{~min}, 61.0 \%$ at $75 \mathrm{~min}, 69.0 \%$ at $90 \mathrm{~min}, 80.0 \%$ at 105 min and above for the ashes of stem (Graphs. A: 4). 
Similarly the bio-materials of TC the $\%$ of extraction of the dye at $\mathrm{pH}: 4$ has been found to be $18.0 \%$ at $15 \mathrm{~min}, 26.0 \%$ at $30 \mathrm{~min}, 37.0 \%$ at $45 \mathrm{~min}, 42.0 \%$ at $60 \mathrm{~min}, 50.0 \%$ at $75 \mathrm{~min}, 55.0 \%$ at $90 \mathrm{~min} 60.0 \%$ at $105 \mathrm{~min}$ or above for leaves powders (Graphs. A: 5); $21.0 \%$ at $15 \mathrm{~min}, 30.0 \%$ at $30 \mathrm{~min}, 40.0 \%$ at 45 $\mathrm{min}, 50.0 \%$ at $60 \mathrm{~min}, 60.0 \%$ at $75 \mathrm{~min}, 65.0 \%$ at $90 \mathrm{~min}, 73.0 \%$ at $105 \mathrm{~min}$ or above (Graphs. A: 6) for leaves ashes; $21.0 \%$ at $15 \mathrm{~min}, 31.0 \%$ at $30 \mathrm{~min}, 40.0 \%$ at $45 \mathrm{~min}, 45.0 \%$ at60 min, $50.0 \%$ at $75 \mathrm{~min}$, $56.0 \%$ at $90 \mathrm{~min}, 64.0 \%$ at $105 \mathrm{~min}$, and above for stem powder (Graphs.A:7); and $30.0 \%$ at $15 \mathrm{~min}$, $35.0 \%$ at $30 \mathrm{~min}, 42.0 \%$ at $45 \mathrm{~min}, 50.0 \%$ at $60 \mathrm{~min}, 56.0 \%$ at $75 \mathrm{~min}, 73 \%$ at $90 \mathrm{~min}$ and above for the ashes of stem (Graphs. A: 8).

\section{pH sensitivity}

The percentage of extraction referred to be $\mathrm{pH}$ sensitive. In the $\mathrm{pH}: 4$ and above the percentage removal of the Methyl Red is more and below this $\mathrm{pH}$ range, the percentage removal has been decreasing (Graphs. B: 1 and 2).

Considering the extract of leaves powder of HY, the maximum extractability, has been found to be $0.0 \%$ at $\mathrm{pH}: 0(1.0 \mathrm{~N} \mathrm{HCl}) 52.0 \%$ at $\mathrm{pH}: 2,68.0 \%$ at $\mathrm{pH}: 4,49.0 \%$ at $\mathrm{pH}: 6,40.0 \%$ at $\mathrm{pH}: 8,35.0 \%$ at $\mathrm{pH}: 10$ compared with the ashes of leaves of HY, the maximum \% removal of the dye has been found to be: 0.0 $\%$ at $\mathrm{pH}: 0(1.0 \mathrm{~N} \mathrm{HCl}), 60.0 \%$ at $\mathrm{pH}: 2,74.0 \%$ at $\mathrm{pH}: 4,56.0 \%$ at $\mathrm{pH}: 6,50.0 \%$ at $\mathrm{pH}: 8,40.0 \%$ at $\mathrm{pH}$ : 10, (Graphs.B:1). With the stem powder of Hyacinth, the $\%$ of extraction has been found to be $0.0 \%$, $60.0 \quad \%, \quad 75.0 \quad \%, \quad 55.0 \quad \%, \quad 40.0 \quad \%, \quad 35.0 \quad \% \quad$ at pH's:0(1.0HCl),2,4,6,8 and10 respectively. The percentage of extraction has been found to be $0.0 \%, \quad 65.0$ $\%, 80.0 \%, 60.0 \%, 45.0 \%$ and,40.0 \% respectively with stem ashes, for the same sequence of pHs (Graphs: B:1).

The plant materials of TC consequently, the maximum percentage removal at $\mathrm{pH}: 0(1.0 \mathrm{~N} \mathrm{HCl}), 2,4,6,8$ and 10 has been found to be $50.0 \%, 60.0 \%, 55.0 \%, 40.0 \%$ and $30.0 \%$ respectively for leaves powder;59.0 \%, $73.0 \%, 64.0 \%, 50.0 \%$ and $40.0 \%$ for leaves ash, $55.0 \%, 64.0 \%, 50.0 \%, 45.0 \%$ and $33.0 \%$ for stem powder; $60.0 \%, 73.0 \%, 58.0 \%, 47.0 \%$ and $35.0 \%$ for stem ash (Graphs.B:2).

\section{Adsorbent Dosage}

When percentage eviction is reviewed with respect to adsorbent dosage at fixed prime $\mathrm{pH}: 4$ and at prime equilibration times, the graphs rise up to certain dosage and from then onwards plateaus are obtained (Graphs. C:1-4). The prime sorbent dosage has been to be less for ashes than the raw plant materials.

In addition to the sorbent pertaining to HY plant, the prime adsorbent congregation has been found to be: $2.5 \mathrm{gm} / \mathrm{L}$ for leaves and $2.0 \mathrm{gm} / \mathrm{L}$ for their ashes, $2.5 \mathrm{gm} / \mathrm{L}$ for stem powders and $2.0 \mathrm{gm} / \mathrm{L}$ for their ashes. For TC plant, the prime sorbent dosage leads to be: $2.0 \mathrm{gm} / \mathrm{L}$ for leaves and $1.75 \mathrm{gm} / \mathrm{L}$ for their ashes, 2.0 $\mathrm{gm} / \mathrm{L}$ for stem powders and $1.5 \mathrm{gm} / \mathrm{L}$ for their ashes. Graphs C: 1 and 4 shows the results.

With the respective raw plant materials, the prime time of agitation is found to be less for ashes. For the stems powder of HY plant, the prime time is found to be $125 \mathrm{~min}$ but $105 \mathrm{~min}$ is sufficient with their ashes as sorbents. With TC leaves powder as adsorbent, the prime agitation time has been found to be 105 min but with their ashes, it has been reduced to $90 \mathrm{~min}$, with stems powder of the same plant, prime equilibration is found to be $125 \mathrm{~min}$ while $90 \mathrm{~min}$ of agitation is enough with ashes stems (Graphs. A: 18).

\section{The following observations were accounted}

The sorbents retrieved from plant materials may have some functional groups like $-\mathrm{OH} / \mathrm{COOH}$ and their dissociation is $\mathrm{pH}$ dependent. This emphasizes poor anion exchange ability at low $\mathrm{pH}: 3$ values and poor cation exchange ability at high $\mathrm{pH}$ values as per the equilibrations: The acid dissociation constant of Methyl Red dye is $\mathrm{pK}: 4.95$ and the dye will be changing from quinonoid form to benzenoid form in the $\mathrm{pH}$ range 4.4-6.2 yielding anion on dissociation. Moreover, the dye is in anionic form and surface is positively charged, adsorption of the dye is more. However, the Vander Waals synergy and Hydrogen bonding formations between surface and dye may abound but these forces will be nullified because of the presence of aquated hydronium ions in the contacting solution of the sorbent surface. 
It is observed that around $\mathrm{pH}: 4$ only the dye shows affinity towards the sorbents. Decrease in sorption may be caused due to Increasing or decreasing of the $\mathrm{pH}$ (other than prime $\mathrm{pH}$ : 4), of the equilibrating solution. Initially, the rate of adsorption is found to be more but reduces with time and reaches study state after certain time. Initially many active sites are available for the sorption process to occur and they are progressively utilised with time and hence, rate of adsorption is reduced. There will not be active sites on the sorbent surface for the adsorption process to take place after certain time as saturation state is reached and during this stage there will not be adsorption further.

\section{Adsorption Isotherms}

Some of the popular adsorption isotherm models such as Freundlich ${ }^{24}$, Langmuir ${ }^{25}$, Temkin ${ }^{26}$ and Dubinin-Radushkevich ${ }^{27}$ isotherms have been adopted to evaluate the relation between the Methyl Red concentrations remaining in the bulk solution to the amount of Methyl Red adsorbed at the solution interface at a constant temperature.

Linear form of Freundlich equation is-

$\log \left(\mathrm{q}_{\mathrm{e}}\right)=\log \mathrm{k}_{\mathrm{f}}+\frac{1}{n} \log \mathrm{C}_{\mathrm{e}}$

Linear form of Langmuir equation is-

$\left.\mathrm{C}_{\mathrm{e}} / \mathrm{q}_{\mathrm{e}}\right)=\left(\mathrm{a}_{\mathrm{L}} / \mathrm{k}_{\mathrm{L}}\right) \mathrm{C}_{\mathrm{e}}+1 / \mathrm{k}_{\mathrm{L}}$

Hall et $a l^{28}$ proposed that the nature of the adsorption process is not rewarding $\left(\mathrm{R}_{\mathrm{L}}>1\right)$, linear $\left(\mathrm{R}_{\mathrm{L}}=1\right)$, favourable $\left(0<\mathrm{R}_{\mathrm{L}}<1\right)$ and irreversible $\left(\mathrm{R}_{\mathrm{L}}=0\right)$ and the significant parameter of the Langmuir isotherm model can be defined by the dimensionless separation factor, $\mathrm{R}_{\mathrm{L}}=1 /\left(1+\mathrm{a}_{\mathrm{L}} \mathrm{C}_{\mathrm{i}}\right)$. The plots which are linear of these two adsorption isotherms were as shown in graphs 1(a)-2(h) (provided in SI file) and isothermal constants along with the correlation coefficient values were presented in Table-1 and 2. As the correlation coefficient ( $\mathrm{R}^{2}$-values) is close to unity, the applicability of these two adsorption isotherms confirmed the heterogeneous surface of the adsorbent and the monolayer coverage of Methyl Red on the bio-sorbents. The applicability of the isotherm equations is compared from the correlation coefficient $\left(\mathrm{R}^{2}\right)$ of these four Isotherm models, the correlation coefficient value of leaves and Bark powders and Ashes of HY and TC for the high correlation coefficient for Freundlich isotherm. $\left(\mathrm{R}^{2}=0.997\right)$ value, Langmuir isotherm $\left(R^{2}=0.976\right)$ and dimensionless separation factor $\left(R_{L}=0.0791\right)$, value which has been found to be fraction in the range of $0-1$, indicate the favourability of the Langmuir isotherm than the Freundlich isotherm. Linear form of Temkin equation is-

$\mathrm{sq}_{\mathrm{e}}=\mathrm{B} \ln \mathrm{Ce}+\mathrm{B} \ln \mathrm{A}$ where $\mathrm{RT} / \mathrm{b}=\mathrm{B}$

Linear form of Dubinin-Radushkevich equation is-

$\ln q_{\mathrm{e}}=-\beta \varepsilon^{2}+\ln \mathrm{qm}$

Where, $\varepsilon=\mathrm{RT} \ln \left(1+1 / \mathrm{C}_{\mathrm{e}}\right)$

Table-1: Freundlich Isotherm

\begin{tabular}{c|c|c|c|c}
\hline S. No. & Name of the sorbent & Slope & Intercept & $\mathrm{R}^{2}$ \\
\hline $1 \mathrm{a}$ & LPOH & 0.393 & 0.849 & 0.996 \\
\hline $1 \mathrm{~b}$ & LAOH & 0.361 & 1.023 & 0.994 \\
\hline $1 \mathrm{c}$ & SPOH & 0.380 & 1.041 & 0.990 \\
\hline $1 \mathrm{~d}$ & SPOH & 0.323 & 1.292 & 0.967 \\
\hline $1 \mathrm{e}$ & LPOTC & 0.356 & 0.625 & 0.964 \\
\hline $1 \mathrm{f}$ & LAOTC & 0.410 & 0.801 & 0.995 \\
\hline $1 \mathrm{~g}$ & BPOTC & 0.392 & 0.886 & 0.997 \\
\hline $1 \mathrm{~h}$ & BAOTC & 0.370 & 1.019 & 0.989 \\
\hline
\end{tabular}

Table-2: Langmuir Isotherm

\begin{tabular}{c|c|c|c|c|c}
\hline S. No. & Name of the sorbent & $\mathrm{R}^{2}$ & Slope & Intercept & $\mathrm{R}_{\mathrm{L}}$ \\
\hline 2a & LPOH & 0.976 & 0.034 & 0.156 & 0.0439 \\
\hline 2b & LAOH & 0.943 & 0.025 & 0.108 & 0.0414 \\
\hline
\end{tabular}


RASĀYAN J. Chem.

Vol. 10 | No. 2 |349 -362 | April - June | 2017

\begin{tabular}{c|c|c|c|c|c}
\hline $2 \mathrm{c}$ & SPOH & 0.976 & 0.024 & 0.089 & 0.0358 \\
\hline $2 \mathrm{~d}$ & SPOH & 0.963 & 0.018 & 0.046 & 0.0250 \\
\hline $2 \mathrm{e}$ & LPOTC & 0.946 & 0.051 & 0.438 & 0.0791 \\
\hline $2 \mathrm{f}$ & LAOTC & 0.969 & 0.038 & 0.159 & 0.0402 \\
\hline $2 \mathrm{~g}$ & BPOTC & 0.960 & 0.031 & 0.148 & 0.0456 \\
\hline $2 \mathrm{~h}$ & BAOTC & 0.968 & 0.025 & 0.096 & 0.0370 \\
\hline
\end{tabular}

Graphs 3(a)-4(h)(provided in SI file) show the linear plots of these two adsorption isotherms and isothermal constants along with the correlation coefficient values were presented in Table- 3 and 4.The correlation coefficients $\left(\mathrm{R}^{2}\right.$-values $)$ are close to unity. The Temkin heat of sorption, $(\mathrm{B}=6.717 \mathrm{jol} / \mathrm{mol})$ was calculated from the slope of the Temkin linear plot $^{29-30}$, and the Dubinin- Radushkevich mean free energy $\mathrm{E}=\sqrt{1 / 2 \beta},{ }^{31}$ was found to be $\mathrm{E}=2.3570 \mathrm{KJ} / \mathrm{mol}$ calculated for the leaves and bark powder and ashes of $\mathrm{HY}$ and TC. As the $\mathrm{E}<8 \mathrm{~kJ} / \mathrm{mol}$, representing 'physical adsorption ${ }^{32}$ upholding the chemical adsorptions and ion exchange etc. The "physical adsorption" is also referred as nonspecific adsorption which occurs as a result of long range weak Vander Waals forces between Methyl Red and adsorbent. According to Atkins ${ }^{33}$, the characteristics for "physical absorption' is the mean free energy (E) and also heats of sorption (B) values lower than $20 \mathrm{~kJ} / \mathrm{mol}$.

Table-3: Temkin Isotherm

\begin{tabular}{c|c|c|c|c|c}
\hline S. No. & Name of the sorbent & B & Slope (B) & Intercept & $\mathrm{R}^{2}$ \\
\hline 1a & LPOH & 51.34 & 4.858 & 7.853 & 0.951 \\
\hline 1b & LAOH & 43.64 & 5715 & 12.76 & 0.879 \\
\hline 1c & SPOH & 40.57 & 6.150 & 13.45 & 0.904 \\
\hline 1d & SPOH & 34.13 & 6.717 & 24.13 & 0.842 \\
\hline 1e & LPOTC & 90.73 & 2.749 & 4.487 & 0.836 \\
\hline 1f & LAOTC & 58.44 & 4.268 & 7.557 & 0.936 \\
\hline 1g & BPOTC & 50.43 & 4.946 & 9.032 & 0.900 \\
\hline 1h & BAOTC & 43.10 & 5.787 & 12.92 & 0.911 \\
\hline
\end{tabular}

Table-4: Dubinin-Radushkevich

\begin{tabular}{c|c|c|c|c|c}
\hline S. No. & Name of the sorbent & $\mathrm{E}$ & Slope $(\mathrm{B})$ & Intercept & $\mathrm{R}^{2}$ \\
\hline 1a & LPOH & 7.0711 & $1 \times 10^{-8}$ & 1.584 & 0.715 \\
\hline 1b & LAOH & 3.1623 & $5 \times 10^{-8}$ & 0.830 & 0.659 \\
\hline 1c & SPOH & 3.5355 & $4 \times 10^{-8}$ & 1.842 & 0.628 \\
\hline 1d & SPOH & 5.0000 & $2 \times 10^{-8}$ & 2.158 & 0.605 \\
\hline 1e & LPOTC & 2.6726 & $7 \times 10^{-8}$ & 1.078 & 0.568 \\
\hline 1f & LAOTC & 2.3570 & $9 \times 10^{-8}$ & 1.469 & 0.603 \\
\hline 1g & BPOTC & 2.6726 & $7 \times 10^{-8}$ & 1.596 & 0.648 \\
\hline 1h & BAOTC & 3.1623 & $5 \times 10^{-8}$ & 1.827 & 0.657 \\
\hline
\end{tabular}

\section{Adsorption Kinetics}

With pseudo first-order model ${ }^{34,35}$ pseudo second-order model ${ }^{35,36}$, Weber and Morris intra particle diffusion model ${ }^{37}$, Bangham's pore diffusion model ${ }^{38}$ and Elovich equations ${ }^{39,40}$ the rate and kinetics of adsorption of methyl red on to the bio-sorbents derived from HY and TC was studied.

The pseudo first-order equation is-

$$
\log (\mathrm{qe}-\mathrm{qt})=\log \mathrm{q}_{\mathrm{e}}-\frac{k 1}{2.303} \times t
$$

The pseudo second-order equation is-

$$
\mathrm{t} / \mathrm{qt}=\frac{1}{k 2 q e 2}+(1 / \mathrm{qe}) \mathrm{t}
$$

Weber and Morris intra particle diffusion equation is- 
RASĀYAN J. Chem.

Vol. 10 | No. 2 |349 -362 | April - June | 2017

$\mathrm{q}_{\mathrm{t}}=\mathrm{k}_{\mathrm{ip}} \mathrm{t}^{1 / 2}+\mathrm{c}$

Bangham's pore diffusion equation is-

$\log \left[\log \left(\mathrm{C}_{\mathrm{i}} / \mathrm{C}_{\mathrm{i}}-\mathrm{q}_{\mathrm{t}} \mathrm{m}\right)\right]=\log (\mathrm{ko} / 2.303 \mathrm{~V})+\alpha \log (\mathrm{t})$

Elovich equation is-

$\mathrm{q}_{\mathrm{t}}=1 / \beta \ln (\alpha \beta)+1 / \beta \ln (\mathrm{t})$

The linear graphs of all these five kinetic models were as shown in graphs 5(a)-9(h) (provided in SI file) and rate constants along with the correlation coefficient values were presented in Tables-5 and 9. The usage of the kinetic equations is compared from the correlation coefficient $\left(\mathrm{R}^{2}\right)$. Of these five kinetic models, the correlation coefficient value of leaves and bark powders and ashes of HY and TC for the Weber and Morris $\left(\mathrm{R}^{2}=0.997\right)$, Bangham's pore diffusion model $\left(\mathrm{R}^{2}=0.994\right)$ pseudo first-order model $\left(\mathrm{R}^{2}=0.978\right)$, pseudo second-order model $\left(\mathrm{R}^{2}=0.987\right)$ and Elovich model $\left(\mathrm{R}^{2}=0.985\right)$.

\section{Effect of Temperature}

By conducting the extraction experiments at different temperatures 298, 308, 318 and $328 \mathrm{~K}$ the effect of solution temperature on the \% removal of Methyl red was studied at prime conditions of extraction: $\mathrm{pH}$ : 4.0; contact time: $90 \mathrm{~min}$; sorbent dosage: $3.0 \mathrm{mg} / \mathrm{L}$; concentration of methyl red dye solution: $100 \mathrm{mg} / \mathrm{L}$; particles size: $45 \mu$ mesh. The results obtained were plotted as $\ln \left(\mathrm{K}_{\mathrm{d}}\right) \mathrm{Vs} 1 / \mathrm{T}$. Thermodynamic parameters of the adsorption process such as change in free energy $(\Delta \mathrm{G}) \mathrm{kJ} / \mathrm{mole}$, change in enthalpy $(\Delta \mathrm{H}) \mathrm{kJ} / \mathrm{mole}$ and change in entropy $(\Delta S) \mathrm{KJ} /$ mole were calculated at different temperatures by using the equations: ${ }^{41-43}$

$\Delta \mathrm{G}=-\mathrm{RT} \ln \left(\mathrm{K}_{\mathrm{d}}\right)$

$\operatorname{Ln}(\mathrm{Kd})=\Delta \mathrm{S} / \mathrm{R}-\Delta \mathrm{H} / \mathrm{RT}$

$\mathrm{K}_{\mathrm{d}}=\mathrm{q}_{\mathrm{e}} / \mathrm{C}_{\mathrm{e}}$ and $\Delta \mathrm{G}=\Delta \mathrm{H}-\mathrm{T} \Delta \mathrm{S}$

Where, $\mathrm{K}_{\mathrm{d}}$ is the distribution coefficient for the adsorption, $\mathrm{q}_{\mathrm{e}}$ is the amount of methyl red adsorbed on the adsorbent per liter of solution at equilibrium, $\mathrm{C}_{\mathrm{e}}$ is the equilibrium concentration of methyl red dye solution is the absolute temperature in Kelvin, $\mathrm{R}$ is the gas constant. $\Delta \mathrm{G}$ is the change in free energy, $\Delta \mathrm{H}$ is the change in enthalpy, $\Delta \mathrm{S}$ is the change in entropy.

Table-5: Pseudo first Order

\begin{tabular}{c|c|c|c|c|c}
\hline S. No. & Name of the sorbent & $\mathrm{K}_{1}$ & Slope $(\mathrm{B})$ & Intercept & $\mathrm{R}^{2}$ \\
\hline 1a & LPOH & 0.0207 & 0.009 & 1.518 & 0.847 \\
\hline 1b & LAOH & 0.0184 & 0.008 & 1.625 & 0.829 \\
\hline 1c & SPOH & 0.023 & 0.010 & 1.674 & 0.894 \\
\hline 1d & SPOH & 0.0207 & 0.009 & 1.800 & 0.974 \\
\hline 1e & LPOTC & 0.0276 & 0.012 & 1.333 & 0.956 \\
\hline 1f & LAOTC & 0.0253 & 0.011 & 1.475 & 0.964 \\
\hline 1g & BPOTC & 0.0209 & 0.009 & 1.399 & 0.978 \\
\hline 1h & BAOTC & 0.0138 & 0.006 & 1.465 & 0.973 \\
\hline
\end{tabular}

Table-6: Pseudo Second Order

\begin{tabular}{c|c|c|c|c|c}
\hline S. No. & Name of the sorbent & $\mathrm{K}_{2}$ & Slope & Intercept & $\mathrm{R}^{2}$ \\
\hline 1a & LPOH & 0.0003 & 0.026 & 1.960 & 0.840 \\
\hline 1b & LAOH & 0.0002 & 0.018 & 1.672 & 0.503 \\
\hline 1c & SPOH & 0.0004 & 0.021 & 1.031 & 0.875 \\
\hline 1d & SPOH & 0.0009 & 0.01 & 1.091 & 0.925 \\
\hline 1e & LPOTC & 0.0006 & 0.040 & 2.497 & 0.961 \\
\hline 1f & LAOTC & 0.00025 & 0.023 & 2.084 & 0.916 \\
\hline $1 \mathrm{~g}$ & BPOTC & 0.00057 & 0.029 & 1.452 & 0.987 \\
\hline $1 \mathrm{~h}$ & BAOTC & 0.00094 & 0.027 & 0.774 & 0.949 \\
\hline
\end{tabular}


RASĀYAN J. Chem.

Vol. 10 | No. 2 |349 -362 | April - June | 2017

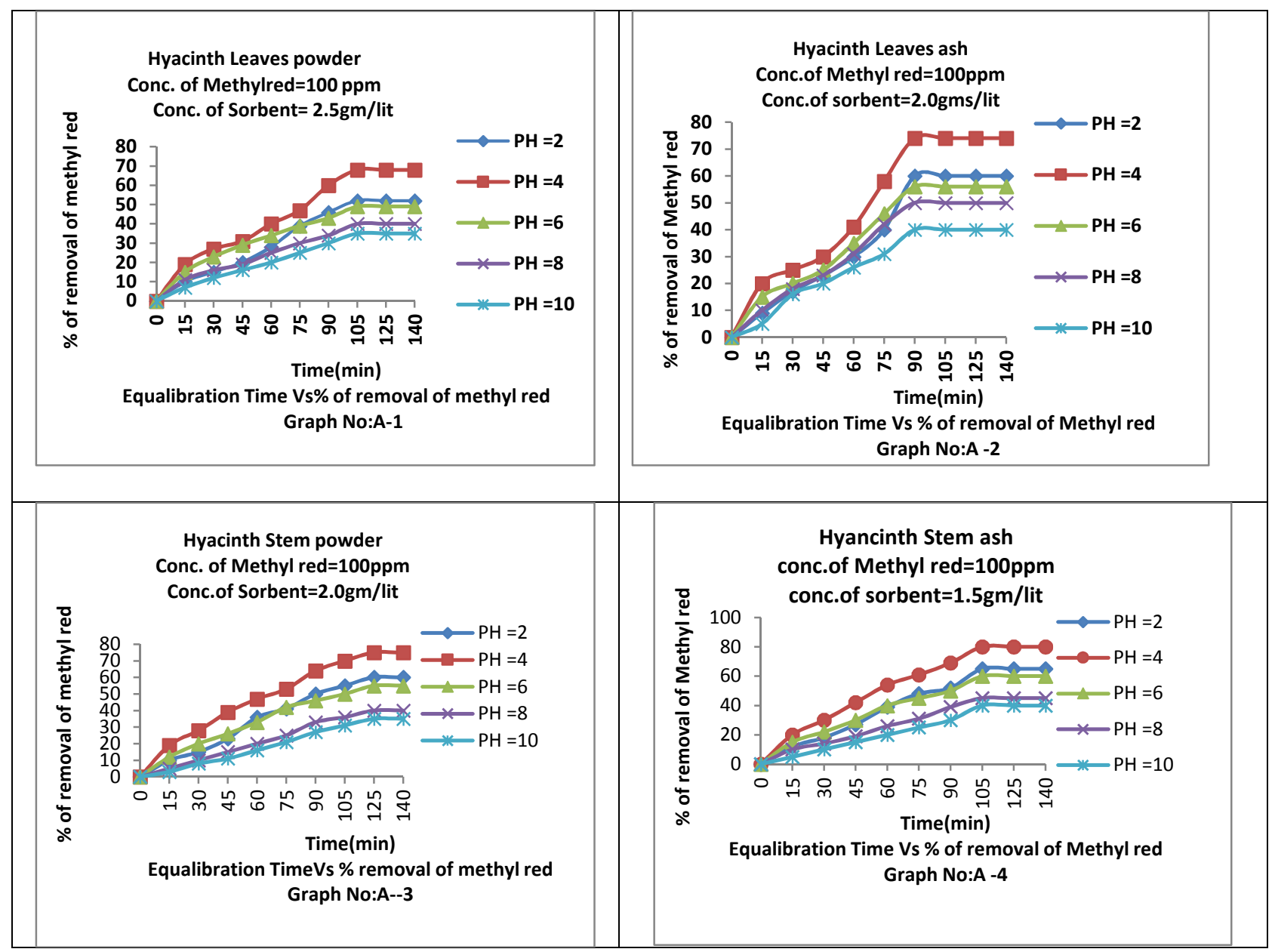

Table-7: Bangham's pore diffusion

\begin{tabular}{c|c|c|c|c|c}
\hline S. No. & Name of the sorbent & $\mathrm{K}_{0}$ & Slope & Intercept & $\mathrm{R}^{2}$ \\
\hline 1a & LPOH & 0.3189 & 0.762 & -1.977 & 0.935 \\
\hline 1b & LAOH & 0.3170 & 0.770 & -1.983 & 0.851 \\
\hline 1c & SPOH & 0.0278 & 0.824 & -1.985 & 0.960 \\
\hline 1d & SPOH & 0.2598 & 0.956 & -2.182 & 0.990 \\
\hline 1e & LPOTC & 0.3095 & 0.786 & -2.007 & 0.990 \\
\hline 1f & LAOTC & 0.3033 & 0.852 & -2.027 & 0.981 \\
\hline 1g & BPOTC & 0.3829 & 0.683 & -1.794 & 0.994 \\
\hline 1h & BAOTC & 0.5423 & 0.515 & -1.446 & 0.942 \\
\hline
\end{tabular}

Table-8: Weber and Morris

\begin{tabular}{c|c|c|c|c}
\hline S. No. & Name of the sorbent & Slope & Intercept & $\mathrm{R}^{2}$ \\
\hline 1a & LPOH & 2.755 & -4.329 & 0.937 \\
\hline $1 \mathrm{~b}$ & LAOH & 3.720 & -6.759 & 0.860 \\
\hline 1c & SPOH & 3.739 & -4.313 & 0.965 \\
\hline $1 \mathrm{~d}$ & SPOH & 5.993 & -11.23 & 0.992 \\
\hline $1 \mathrm{e}$ & LPOTC & 1.928 & -2.623 & 0.993 \\
\hline $1 \mathrm{f}$ & LAOTC & 2.732 & -4.324 & 0.988 \\
\hline $1 \mathrm{~g}$ & BPOTC & 2.458 & -0.991 & 0.997 \\
\hline $1 \mathrm{~h}$ & BAOTC & 3.569 & -1.123 & 0.904 \\
\hline
\end{tabular}


RASĀYAN J. Chem.

Vol. 10 | No. 2 |349 -362 | April - June | 2017

Table-9: Elovich

\begin{tabular}{c|c|c|c|c}
\hline S. No. & Name of the sorbent & Slope & Intercept & $\mathrm{R}^{2}$ \\
\hline 1a & LPOH & 8.334 & -16.77 & 0.868 \\
\hline 1b & LAOH & 10.48 & -21.02 & 0.776 \\
\hline 1c & SPOH & 12.14 & -23.96 & 0.948 \\
\hline 1d & SPOH & 18.51 & -39.75 & 0.958 \\
\hline 1e & LPOTC & 5.973 & -11.86 & 0.965 \\
\hline 1f & LAOTC & 8.411 & -17.22 & 0.949 \\
\hline 1g & BPOTC & 7.682 & -13.02 & 0.985 \\
\hline 1h & BAOTC & 10.71 & -16.91 & 0.825 \\
\hline
\end{tabular}

The values of $\Delta \mathrm{H}$ and $\Delta \mathrm{S}$ were calculated from the slope and intercept of a plot between $\ln \left(\mathrm{K}_{\mathrm{d}}\right)$ and $1 / \mathrm{T}$ and $\Delta \mathrm{G}$ values were calculated from the equation $\Delta \mathrm{G}=\Delta \mathrm{H}-\mathrm{T} \Delta \mathrm{S}$ and tabulated ${ }^{44-45}$.

With increase in temperature from 298 to $328 \mathrm{~K} 25$ to $55^{\circ} \mathrm{C}$, the maximum extraction of methyl red takes place at $328 \mathrm{~K}$. The thickness of outer surface of the adsorbent decreases and kinetic energy of the methyl red increases as the temperature increases. Therefore, the rate of diffusion of methyl red increases across the external boundary layer and internal pores of the adsorbent.

From Table-10 it can be inferred that, the values of $\Delta \mathrm{H}$ are positive, indicating the physical sorption and endothermic nature of adsorption ${ }^{46}$. The $\mathrm{R}^{2}$ values close to one also indicates that adsorption process is endothermic nature. The +ve values of $\Delta \mathrm{S}$ represent the increased disorder and randomness at the solid solution interface of methyl red dye with the adsorbent ${ }^{47}$. The -ve values of $\Delta \mathrm{G}$ indicate the spontaneous nature of adsorption process i.e. the adsorptive forces are strong enough to overcome the potential barrier $^{48 .}$

Table-10: Effect of temperature: parameter (temp.(K))

\begin{tabular}{c|c|c|c|c|c}
\hline S. No. & Name of the sorbent & $\begin{array}{c}\Delta \mathrm{H} \\
\mathrm{kJ} / \mathrm{mol})\end{array}$ & $\begin{array}{c}\Delta \mathrm{S} \\
(\mathrm{J} / \mathrm{mol} / \mathrm{K})\end{array}$ & $\begin{array}{c}\Delta \mathrm{G} \\
(\mathrm{kJ} / \mathrm{mol})\end{array}$ & $\mathrm{R}^{2}$ \\
\hline 1a & LPOH & 7.51419 & 0.021034 & 0.6149 & 0.950 \\
\hline 1b & LAOH & 8.7130 & 0.028957 & -0.7851 & 0.985 \\
\hline 1c & SPOH & 8.9624 & 0.030088 & -0.9066 & 0.957 \\
\hline 1d & SPOH & 9.9019 & 0.037687 & -2.4596 & 0.984 \\
\hline 1e & LPOTC & 7.4709 & 0.015289 & 2.4560 & 0.988 \\
\hline 1f & LAOTC & 8.1510 & 0.023628 & 0.4008 & 0.966 \\
\hline 1g & BPOTC & 7.6564 & 0.020045 & 1.0816 & 0.988 \\
\hline 1h & BAOTC & 8.2483 & 0.027140 & -0.6526 & 0.989 \\
\hline
\end{tabular}

$\mathrm{LPOH}=$ Leaves Powder of Hyacinth

LPOTC $=$ Leaves Powder of Tinospora Cordifolia

$\mathrm{LAOH}=$ Leaves Ash of Hyacinth

LAOTC $=$ Leaves ash of Tinospora Cordifolia

$\mathrm{SPOH}=$ Bark powder of Hyacinth

BPOTC $=$ Bark powder of Tinospora Cordifolia

$\mathrm{SAOH}=$ Bark ash of Hyacinth

$\mathrm{BAOTC}=$ Bark ash of Tinospora Cordifolia

\section{Effect of interfering ions}

The effect of the inclusion of fivefold excess of co-ions on the extraction of the methyl red dye from simulated waters, is presented in the Table-11. It can be stated that bivalent anions likeCO${ }_{3}^{2-}$ and $\mathrm{SO}_{4}{ }^{2-}$ and $\mathrm{PO}_{4}{ }^{3-}$ interfered markedly while monovalent ions like $\mathrm{Cl}$ - and $\mathrm{NO}^{3-}$ interfered to a less extent. The \% of extraction without co- ions has been found be fluctuating from $70.5 \%$ to $86.0 \%$ with the eight sorbents developed in this work but the extraction has been seriously affected to $15.0 \%$ to $29.0 \%$ in presence of fivefold excess of $\mathrm{SO}^{2-}, 11.0$ to $22.0 \%$ with Phosphate, and 21.0 to $29.0 \%$ with $\mathrm{CO}_{3}{ }^{2-}$, with monovalent co-anions, the \% of extraction of the dye, has been found to be reduced to $56.0 \%$ to $69.0 \%$ for $\mathrm{Cl}^{-}$and 55.0 to $66.0 \%$ for $\mathrm{NO}^{3-}$. 
The co-cations studied viz., $\mathrm{Ca}^{2+}, \mathrm{Mg}^{2+}, \mathrm{Fe}^{2+}, \mathrm{Zn}^{2+}$ and $\mathrm{Cu}^{2+}$ have less interfered with the $\%$ of extraction of the dye. 70.5 to $86.0 \%$ extraction of the dye in the absence of the co-ions, has been reduced to 53.0$67.5 \%$ in presence fivefold excess of $\mathrm{Ca}^{2+}, 47.8-56.0 \%$ for $\mathrm{Cu}^{2+}, 54.0-65.0 \%$ for $\mathrm{Fe}^{2+}, 54.0-63.0 \%$ for $\mathrm{Zn}^{2+}$ and $57.0-63.0 \%$ for $\mathrm{Mg}^{2+}$.

\section{Applications of the Developed Bio-sorbents}

The developed methodologies have been applied for samples collected from the effluents of Dyeing industries, sewages which are fed with varying quantities of the Methyl Red dye. Table-12 shows the results. It is shown from the data that $80-90 \%$ Methyl Red dye can be removed from the waste waters.

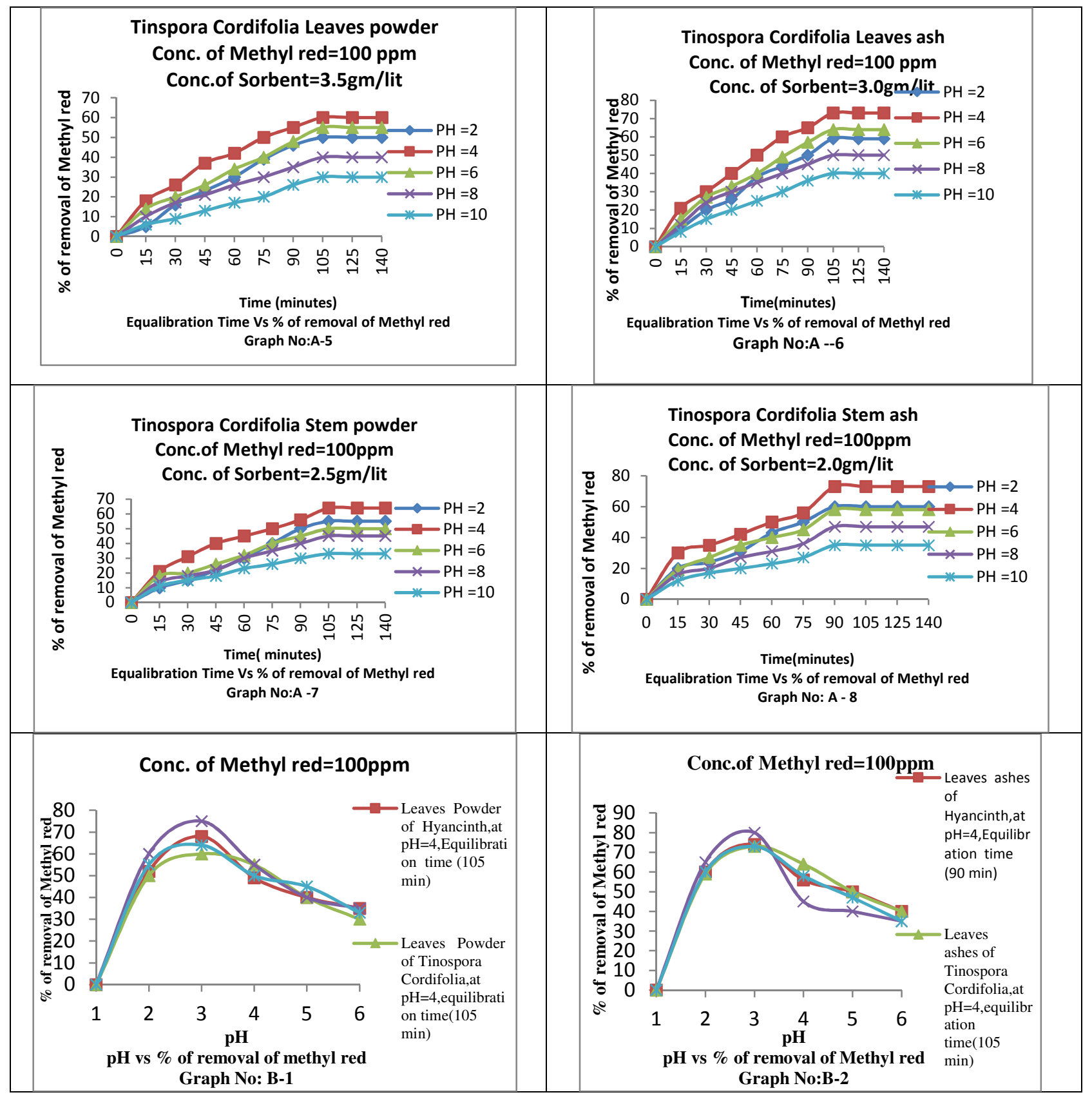


RASĀYAN J. Chem.

Vol. 10 | No. 2 |349 -362 | April - June | 2017

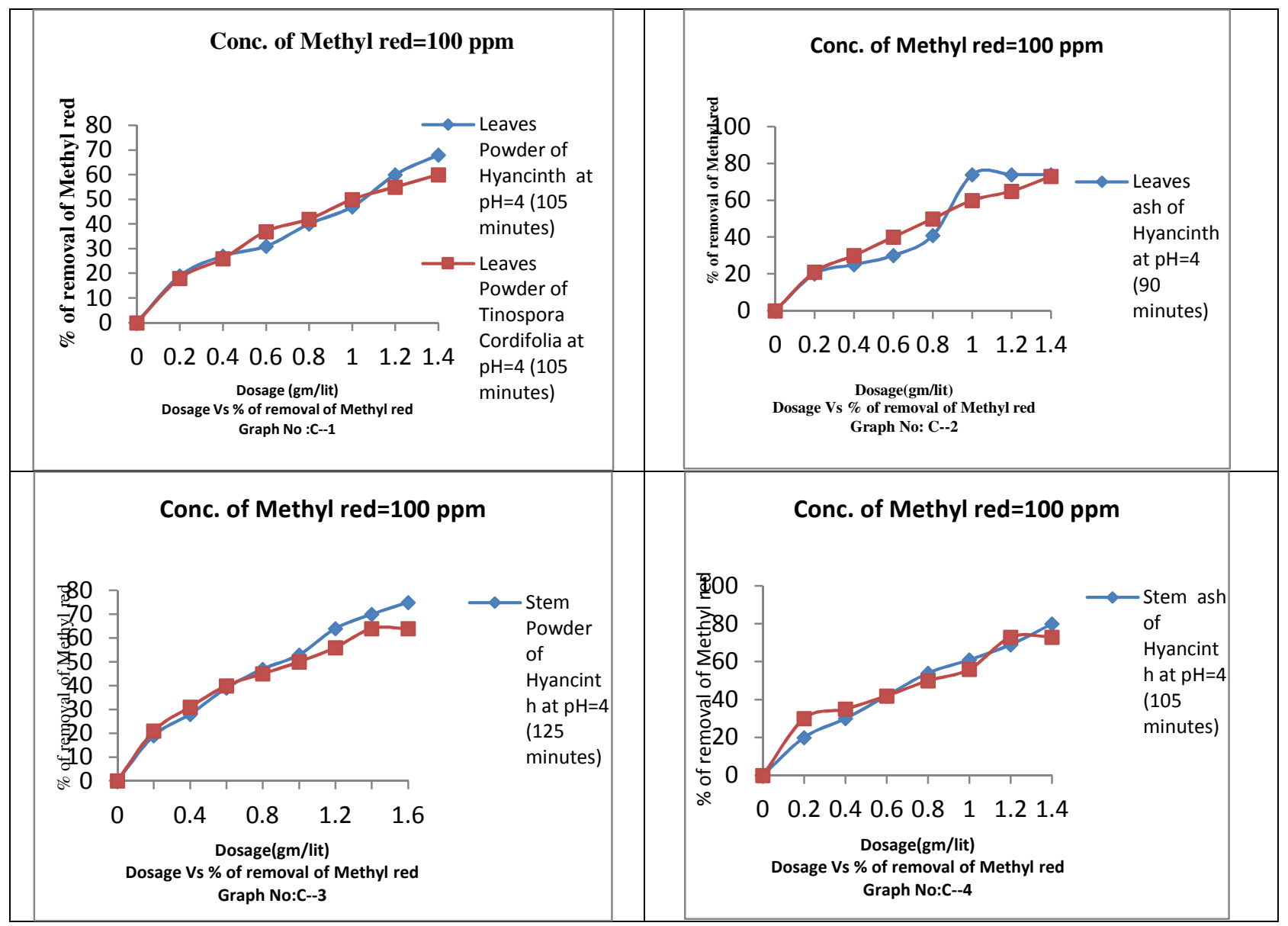

Table-11: Effect of interfering Ions on the Extractability of Methyl Red with different Bio-sorbents: 65 to 99 between values

\begin{tabular}{|c|c|c|c|c|c|c|c|c|c|c|c|c|}
\hline \multirow{2}{*}{$\begin{array}{l}\text { S. } \\
\text { No. }\end{array}$} & \multirow{2}{*}{$\begin{array}{l}\text { Adsorbent and its } \\
\text { concentration }\end{array}$} & \multirow{2}{*}{$\begin{array}{l}\text { Maximum } \\
\text { Extractability } \\
\text { at prime } \\
\text { conditions }\end{array}$} & \multicolumn{10}{|c|}{$\begin{array}{c}\% \text { of Extraction of Methyl Red in presence fivefold excess of } \\
\text { interfering ions at prime conditions: Conc. of Methyl Red : } 100 \mathrm{ppm} \\
\text { at } \mathrm{pH}: 4\end{array}$} \\
\hline & & & $\mathrm{SO}_{4}^{2-}$ & $\mathrm{PO}_{4}{ }^{3-}$ & $\mathrm{Cl}^{-}$ & $\mathrm{CO}_{3}{ }^{2-}$ & $\mathrm{F}^{-}$ & $\mathrm{Fe}^{2+}$ & $\mathrm{Ca}^{2+}$ & $\mathrm{Mg}^{2+}$ & $\mathrm{Cu}^{2+}$ & $\mathrm{Zn}^{2+}$ \\
\hline 1 & $\begin{array}{l}\text { Leaves Powder of } \\
\text { Hyacinth:2.5gms/lit }\end{array}$ & $\begin{array}{c}68.0 \% ; \\
\mathrm{pH}: 4,105 \mathrm{~min}\end{array}$ & 79.0 & 82.1 & 84.2 & 87.0 & 86.0 & 82.5 & 67.5 & 74.0 & 68. & 63.0 \\
\hline 2 & $\begin{array}{l}\text { leaves Powder of } \\
\text { Tinospors } \\
\text { Cordifolia: } 2.0 \text {.gms/lit }\end{array}$ & $\begin{array}{c}74.0 \% \\
\mathrm{pH}: 4,90 \mathrm{~min}\end{array}$ & 83.0 & 89.2 & 92.0 & 88.9 & 91.2 & 86.6 & 83.4 & 66.5 & 89.4 & 93.0 \\
\hline 3 & $\begin{array}{c}\text { Bark Powder of } \\
\text { Hyacinth 2.0gms/lit }\end{array}$ & $\begin{array}{c}75 \% ; \\
\mathrm{pH}: 4,125 \min \end{array}$ & 77.0 & 69.2 & 87.5 & 82.1 & 98.3 & 77.5 & 69.1 & 68.3 & 77.5 & 85.5 \\
\hline 4 & $\begin{array}{l}\text { Bark Powder of } \\
\text { Tinospors Cordifolia } \\
\text { 2.5gms/lit }\end{array}$ & $\begin{array}{c}64.0 \% \\
\mathrm{pH}: 4,105 \min \end{array}$ & 92.0 & 77.5 & 84.2 & 87.0 & 86.0 & 82.5 & 67.5 & .0 & 68.0 & 63.0 \\
\hline 5 & $\begin{array}{c}\text { leaves Ashes of } \\
\text { Hyacinth } ; 2.0 \mathrm{gms} / \mathrm{lit}\end{array}$ & $\begin{array}{c}74.0 \% \\
\mathrm{pH}: 4,90 \mathrm{~min}\end{array}$ & 83.1 & 84.0 & 85.0 & 88.1 & 92.0 & 89.5 & 83.1 & 80.0 & 78.5 & 83.0 \\
\hline 6 & $\begin{array}{l}\text { leaves Ashes of } \\
\text { Tinospors } \\
\text { Cordifolia; } 3.0 \text { gms/lit }\end{array}$ & $\begin{array}{c}73 \% ; \\
\mathrm{pH}: 4,105 \text { min }\end{array}$ & 79.2 & 81.4 & 85.7 & 86.5 & 85.2 & 81.3 & 67.1 & 73.8 & 67.6 & 64 \\
\hline 7 & $\begin{array}{c}\text { Bark Ashes of } \\
\text { Hyacinth } 1.5 \text { gms /lit }\end{array}$ & $\begin{array}{c}80.0 \% \\
\mathrm{pH}: 4,105 \text { min }\end{array}$ & 82.6 & 83.2 & 84.6 & 87.2 & 91.8 & 88.0 & 82.4 & 79.2 & 77.6 & 82.1 \\
\hline 8 & $\begin{array}{l}\text { Bark Ashes of } \\
\text { Tinospors Cordifolia } \\
\text { 2.ogms/lit }\end{array}$ & $\begin{array}{c}73.0 \% \\
\mathrm{pH}: 4,90 \mathrm{~min}\end{array}$ & 89.5 & 86.2 & 86.1 & 78.5 & 92.1 & 98.5 & 68.3 & 74.0 & 68.0 & 63.0 \\
\hline
\end{tabular}


RASĀYAN J. Chem.

Vol. 10 | No. 2 |349 -362 | April - June | 2017

Table-12: \% of Extractability of Methyl Red from effluents with bio-sorbents developed in this work. 80 to 90 between values

\begin{tabular}{|c|c|c|c|c|c|c|}
\hline \multirow[b]{2}{*}{ Bio-Sorbents } & \multicolumn{6}{|c|}{$\%$ of extraction of methyl red in diverse samples } \\
\hline & $\begin{array}{l}\text { Sample }-1 \\
\text { Fed with } \\
\text { 10.0ppm } \\
\text { methyl red } \\
\text { dye }\end{array}$ & $\begin{array}{l}\text { Sample }-2 \\
\text { Fed with } \\
\text { 15.0ppm } \\
\text { methyl red } \\
\text { dye }\end{array}$ & $\begin{array}{l}\text { Sample }-3 \\
\text { Fed with } \\
\text { 20.0ppm } \\
\text { methyl red } \\
\text { dye }\end{array}$ & $\begin{array}{c}\text { Sample }-4 \\
\text { Fed with } \\
25.0 \mathrm{ppm} \\
\text { methyl red } \\
\text { dye } \\
\end{array}$ & $\begin{array}{l}\text { Sample }-5 \\
\text { Fed with } \\
\text { 30.0ppm } \\
\text { methyl red } \\
\text { dye }\end{array}$ & $\begin{array}{c}\text { Sample }-6 \\
\text { Fed with } \\
35.0 \mathrm{ppm} \\
\text { methyl red } \\
\text { dye } \\
\end{array}$ \\
\hline $\begin{array}{l}\text { Powder of Hyacinth } \\
\text { leaves:3.0 gms/lit }\end{array}$ & 81.5 & 90.0 & 82.3 & 81.2 & 85.5 & 86.3 \\
\hline $\begin{array}{c}\text { Powder of Tinospors } \\
\text { Cordifolia leaves: } 2.0 \mathrm{gms} / \mathrm{lit}\end{array}$ & 83.5 & 91.1 & 85.5 & 88.3 & 87.4 & 82.1 \\
\hline $\begin{array}{c}\text { Powder of Hyacinth Bark } \\
2.5 \text { gms/lit }\end{array}$ & 88.1 & 82.2 & 85.6 & 88.3 & 81.5 & 83.5 \\
\hline $\begin{array}{c}\text { Powder of Tinospors } \\
\text { Cordifolia bark 2.0gms/lit }\end{array}$ & 89.1 & 88.2 & 85.2 & 86.4 & 88.2 & 85.5 \\
\hline $\begin{array}{c}\text { Ashes of } \\
\text { Hyacinth leaves; } 2.5 \mathrm{gms} / \text { lit }\end{array}$ & 87.3 & 81.5 & 85.5 & 85.4 & 89.0 & 85.2 \\
\hline $\begin{array}{c}\text { Ashes of Tinospors } \\
\text { Cordifolialeaves } ; 1.75 \mathrm{gms} / \mathrm{lit}\end{array}$ & 88.5 & 82.3 & 86.4 & 81.5 & 85.3 & 84.6 \\
\hline $\begin{array}{c}\text { Ashes of Hyacinth Bark } \\
2.0 \mathrm{gms} / \mathrm{lit}\end{array}$ & 86.5 & 88.3 & 89.0 & 85.2 & 83.5 & 86.5 \\
\hline $\begin{array}{c}\text { Ashes of Tinospors Cordifolia } \\
\text { bark 1.5gms/lit }\end{array}$ & 86.3 & 86.5 & 84.4 & 88.3 & 89.5 & 83.5 \\
\hline
\end{tabular}

\section{CONCLUSION}

For the sorption abilities towards Methyl Red dye from polluted waters is due to Bio-adsorbents derived from plant materials of Hyacinth and Tinospors Cordifolia. Extraction parameters such as sorbent dosage, $\mathrm{pH}$, and time of equilibration have been adaptive for the maximum removal of Methyl Red dye. \% removal of the dye is high when the $\mathrm{pH}$ of the extraction system is approximately 4 . Ashes found to be more effective than respective raw bio-materials. Fivefold excess of di- and trivalent co-anions found to be interfering while the monovalent anions to a less extent. Co-cations have showed less interference.

The four Isotherm models, the correlation coefficient value of leaves and bark powders and ashes of HY and TC for the high correlation coefficient for Freundlich isotherm $\left(\mathrm{R}^{2}=0.9965\right)$ value, Langmuir isotherm $\left(R^{2}=0.9964\right)$ and dimensionless separation factor $\left(R_{L}=0.0901\right)$ value which has been found to be fraction in the range of $0-1$, indicate the favourability of the Langmuir isotherm than the Freundlich isotherm. The correlation coefficient value of leaves and bark powders and ashes of Hyacinth and TC for the Weber and Morris $\left(\mathrm{R}^{2}=0.991\right)$, Bangham's pore diffusion model $\left(\mathrm{R}^{2}=0.992\right)$ pseudo first-order model $\left(R^{2}=0.982\right)$, pseudo second-order model $\left(R^{2}=0.951\right)$ and Elovich model $\left(R^{2}=0.979\right)$. It is observed that the pseudo second-order model fits well to the experimental data of the proposed adsorption system. The values of $\Delta \mathrm{H}$ are +ive, indicating the physical sorption and endothermic nature of adsorption.

\section{REFERENCES}

1. H. Zollinger, Color chemistry, VCH Publishers., New York (1987).

2. $\quad$ E.S. Abrahat, Dyes and their intermediates, Edward Arnolds Ltd. London., UK (1977).

3. M. Neamtu, I.Siminiceanu, A. Yediler, and A. Kettrup, Dyes Pigments., 53, 93(2002).

4. C. F. Gurnham, Industrial waste control, academic press., New York (1965).

5. J.P. Jadhav, G. K. Parshetti, S.D. Kalme, and S. P.Govindwar, Decolourization of azo dye methyl red by Saccharomyces cerevisiaeMTCC 463. Chemosphere., 68, 94(2007).

6. Y. Anjaneyulu, N.S. Chary, and D.S.S. Raj, Decolourization of industrial effluents- available methods and emerging technologies - a review. Rev. Environ. Sci. Biotehnol., 4, 245(2005). 
7. B. Gopal, Conservation of inland waters in India, An overview, Verh. Internat.VereinLimnol., 25, 2494(1994).

8. T. Robinson, G. McMullan, R. Marchant, and P. Nigam, Remediation of dyes in textile effluent: a critical review on current treatment technologies with a proposed alternative. Bioreso. Tech., 77, 247(2004).

9. C.I. Pearce, J.R. Lloyd, and J.T. Guthrie, The removal of colour from textile waste water using whole bacterial cells: A review. Dyes Pigm., 58, 179(2003).

10. J. A. Laszlom, Preparing an ion exchange resin from sugarcane bagasse to removereactive Dye from wastewater. Text Chem Color., 28(5), 13(1996).

11. A.H. Gemea, I.A. Mansour, R.G. El-Sharkawy, and A.B. Zaki, Kinetics and mechanism of the heterogeneous catalyzed oxidative degradation of indigo carmine, J. Mol.Catal. Chem., 193 (1-2) 109(2003).

12. V.L. Grimau, and M.C. Gutierrez, Decolorization of simulated reactive Dyebath effluents by electrochemical oxidation assisted by UV light, Chemosphere., 62, 106(2006).

13. C. Hachem, F. Bocquillon, O. Zahraa, and M. Bou.chy, Decolorization of textil industry Wastewater by the photocatalytic degradation process., Dyes Pigm., 49, 117(2001).

14. R.L. Cisneros, A.G. Espinoza, and M.I. Litter, Photo.degradation of an azo Dye of the textile industry. Chemosphere., 48, 393(2002).

15. V.K. Gupta Suhas, Application of low-cost adsorbents for Dye removal-A review. J. Environ. Manage., 90, 2313(2009).

16. V. Srivastava, I.D. Mall, and I.M. Mishra, Equilibrium modelling of single and binary adsorption of cadmium and nickel onto bagasse fly ash. Chem. Eng. J., 117, 79(2006).

17. A. Bes-Pia, J.A. Mendoza-Roca, and M.I. Alcaina-Miranda, Combination of physico-chemical treatment and nanofiltration to reuse wastewater of a printing, dyeing and finishing textile industry. Desalination., 157, 73(2003).

18. D. Georgiou, A. Aivazidis, and J. Hatiras, Treatment of cotton textile waste water using lime and ferrous sulfate. Water Res., 37, 2248(2003).

19. A. Baban, A. Yediler, and D. Lienert, Ozonation of high strength segregatedeffluents from a woolen textile dyeing and finishing plant. Dyes Pigments., 58, 93(2003).

20. T. Kurbus, Y. March Slokar, A. Majcen, The use of experimental designfor the evaluation of the influence of variables on the $\mathrm{H}_{2} \mathrm{O}_{2}$ / UV treatment of model textile waste water. Dyes Pigments., 58, 171(2003).

21. R.K. Trivedy, Pollution Management in Industries, 2nd ed. Karad (India): Environmental Publications., (1995).

22. Gerard Kiely, Environmental Engineering, McGraw-hall International Editions., (1998).

23. Metcalf and Eddy, Wastewater Engineering: Treatment of Reuse. 4th. Ed, New York: McGraw Hill Co., (2002).

24. H.M.F. Freundlich, J. Phys. Chem., 57, 385(1906).

25. I. Langmur, J. Am. Chem. Soc., 40, 1361(1918).

26. M.J. Temkin, and V. Pyzhev, Acta Physiochim., U.S.S.R. 12, 217(1940)

27. M.M. Dubinin, and L.V. Radush Kevich, Phys. Chem. Sect., 55, 331(1947).

28. K.R. Hall, L.C.Eagleton, and A. Acrivos, T. Vermevlem, Ind. Eng. Chem. Fundam., 5, 212(1966).

29. B.H. Hameed, J. Hazard.Mater., 162, 939(2009).

30. A. Nunes, S.A. Franca, and L.S. Olievera, Bioresource Technology., 100, 1786(2009).

31. M.S. Onyango, Y. Kojima, O. Aoyi, E.C. Bernardo, and H. Matsuda. J. Colloid Interface Sci., 279, 341 (2004).

32. J. Monika, V. Garg, and K. Kadirvelu, J. Hazardous materials., 162, 365(2009).

33. P. Atkins, Physical chemistry 6th Edn. Oxford University press, London., 857 (1999).

34. S. Lagergren, and Handlingar., 24 (4), 1(1898).

35. Y.S. Ho, and G. McKay, Process Biochem., 34, 451(1999).

36. Y.S. Ho, J.C.Y. Ng, and G. McKay, Purif. Methods., 29, 189(2000). 
RASĀYAN J. Chem.

Vol. 10 | No. 2 |349-362 | April - June | 2017

37. W.J. Weber Jr, and C. Morris, J. Sanit. Eng. Div., 89, 31(1963).

38. C. Aharoni, and M. Ungarish, J. Chem. Soc. Faraday Trans 1, Phys. Chem. Condens. Phases., 73(3), 456(1977).

39. M. Ozacar, and I. A. Sengil, Process Biochem., 4, 565(2007).

40. C. Gerente, V.K.C. Lee, P. Le Cloirec, and G. McKay, Crit. Rev. Environ. Sci.Techno.,37, 41(2007).

41. G. Alagumuthu, and M. Rajan, Hem. Ind., 64(4), 295(2010).

42. G. Karthikeyan, and S.S. ivaElango. Iran J. Environ. Health. Sci. Eng., 4(1), 21(2007).

43. M. Sekar, V. Sakthi, and S. Rengaraj, J. Colloid Interface Sci., 279, 307(2004).

44. M. Horsfall, and A. Spiff, J. Biotechnol., 8, 162(2005).

45. N. Viswanathan, and S. Meenakshi, J. Hazard. Mater., 178, 226(2010).

46. Z. Bouberka, S. Kaoha, Kamecha, S. Elmaleh, and Z. Derriche, J. Hazard. Mat., 119, 117(2005).

47. C. Sairam, Sundaram, N. Viswanathan, and S.J. Meenakshi, Hazard.Mater., 163(2-3), 618 (2009).

48. A.K. Chaturvedi, K.C. Pathak K, and V.N. Singh, Appl. Clay Sci., 3, 337(1988).

[RJC-1537/2016] 